\title{
Agranular Platelets Count
}

National Cancer Institute

\section{Source}

National Cancer Institute. Agranular Platelets Count. NCI Thesaurus. Code C147415.

The determination of the amount of ag ranular platelets present in a sample. 